\title{
Heavy Metal Concentrations in Fish from River Tano in Ghana and the Health Risks Posed to Consumers
}

\author{
A. J. Nyantakyi $\mathbb{D},{ }^{1}$ S. Wiafe $\mathbb{D}^{2},{ }^{2}$ O. Akoto, ${ }^{3}$ and Bernard Fei-Baffoe $\mathbb{D}^{4}$ \\ ${ }^{1}$ Environmental Protection Agency, P. O. Box GS 166, Ahafo Regional Office, Accra, Ghana \\ ${ }^{2}$ Sunyani Technical University, Sunyani, Ghana \\ ${ }^{3}$ Department of Chemistry, Kwame Nkrumah University of Science and Technology, Kumasi, Ghana \\ ${ }^{4}$ Department of Environmental Science, Kwame Nkrumah University of Science and Technology, Kumasi, Ghana \\ Correspondence should be addressed to S.Wiafe; samwafy@yahoo.co.uk
}

Received 4 June 2021; Revised 6 September 2021; Accepted 6 October 2021; Published 8 November 2021

Academic Editor: Sina Dobaradaran

Copyright (c) 2021 A. J. Nyantakyi et al. This is an open access article distributed under the Creative Commons Attribution License, which permits unrestricted use, distribution, and reproduction in any medium, provided the original work is properly cited.

\begin{abstract}
Appreciable levels of trace metals have been reported in the Tano basin, but data on the corresponding levels in fish and the risk they pose to consumers are limited. The levels of 7 trace metals in 18 fish muscles were assessed between November 2016 and October 2017 using acid digestion and PerkinElmer (PinAACle 900T) Atomic Absorption Spectrophotometry. Apart from Cu, all the metals studied were detected in all fish samples. The levels of $\mathrm{Cr}$, As, and $\mathrm{Hg}$ were higher than the acceptable levels of fish muscles. Cr concentration ranged from $16.10 \pm 0.2 \mathrm{mg} / \mathrm{kg}$ in Clarias gariepinus to $57.9 \pm 4.2 \mathrm{mg} / \mathrm{kg}$ in Sarotherodon galilaeus. The levels of As ranged from $1.01 \pm 0.08$ in Clarias gariepinus to $3.00 \pm 0.01 \mathrm{mg} / \mathrm{kg}$ in Mormyrus rume. Hg level was $0.58 \pm 0.69 \mathrm{mg} / \mathrm{kg}$ in Oreochromis niloticus and $2.52 \pm 0.70 \mathrm{mg} / \mathrm{kg}$ in Ctenopoma kingsleyae. However, $\mathrm{Pb}, \mathrm{Zn}$, and $\mathrm{Cd}$ concentrations were below the Food and Agriculture Organization limits with low target hazard quotients in all fish samples, suggesting no possible noncarcinogenic risks to adult consumers. Possible noncarcinogenic and carcinogenic health risks were recorded for $\mathrm{As}, \mathrm{Hg}$, and $\mathrm{Cr}$ in all fish species. Strong associations were observed between $\mathrm{Hg}, \mathrm{As}, \mathrm{Zn}$, and $\mathrm{Cr}$ and between $\mathrm{Pb}$ and $\mathrm{Cd}$ suggesting a possible common source. Mormyrus rume fish species was under stress in the river, but the remaining species were in good condition. Periodic monitoring of trace metal concentrations in fish and enforcement of the buffer zone policy are recommended.
\end{abstract}

\section{Introduction}

Fish continue to be the main source of protein worldwide, yet trace metal pollution endangers them $[1,2]$. Fish protein has some nutritional and therapeutic benefits [3]. Trace metal pollution originates from natural and human activities, including industrial effluent discharges, atmospheric deposition, mining, agricultural runoffs, and urbanization $[4,5]$. Runoffs from agricultural activities contain appreciable concentrations of trace metals [6]. Fish in heavy metal polluted water are susceptible and vulnerable to toxicological problems because of their feeding habits and location in water environments [7-9]. Fish exposure to toxicants has had some harmful effects on their quality, diversity, and health of humans who depend on them for their protein needs [10]. For example, higher concentrations of Cd above
$0.5 \mathrm{mg} / \mathrm{kg}$ in fish alter carbohydrate and protein metabolism [11]. Trace metals in sediments and water threaten aquatic life $[3,9]$. This is due to their bioaccumulation, biomagnification through the food chain, and their potential threats to human health $[12,13]$. Metals deposited in rivers are immobilized and deposited into sediment through adsorption onto suspended particles, ion exchange with organic matter, incorporation into the mineral lattice structure, and precipitation as insoluble metals [12, 13]. In the water column, trace metals presence is enhanced by their solubility, mobility, and adsorption properties in the medium [14-16]. Metals including $\mathrm{Cu}$ and $\mathrm{Zn}$ in smaller concentrations are said to be important for the regular physiological and central functions of organisms including fish [17]. However, higher concentrations result in toxicological problems [18]. 
Fish concentrate heavy metals in their tissues and for this reason may be used in estimating the level of pollution in the aquatic ecosystems $[19,20]$. The concentrations of micropollutants in fish depend on the body size, age, location in the water, physicochemical properties of the water, and their feeding habits [21]. The consumption of fish with heavy metals above the recommended limits leads to health problems including kidney, liver, brain, nervous, and skin complications and death $[10,17,22]$. Consequently, increasing metal concentrations in fish has been a grave global concern over the decades $[23,24]$.

In fast moving rivers, fish can travel through greater distances [2]. However, their movements may be impeded by physical obstacles, changes in $\mathrm{pH}$, temperature, and turbidity. Studies conducted by Nyantakyi et al. [25] on trace metals in water and sediment samples from the Tano Basin have revealed appreciable levels of $\mathrm{Hg}, \mathrm{Cd}$, and As. Fish exposed to higher contaminants, including heavy metals, absorb the bioavailable forms directly from the aquatic environment $[12,26]$. Communities located in the downstream of River Tano depend on fish from the river for their protein needs. However, data on the concentrations of trace metals in fish from River Tano and the risk they pose to the consumers are limited. This research sought to assess trace metals levels in the muscles of fish samples from River Tano in Ghana and the hazards they pose to consumers. The information could also be used to adopt some pollution control strategies and make informed decisions.

\section{Materials and Methods}

2.1. Study Area. The midstream end of the Tano Basin, which covers the Asunafo South district of the Ahafo Region of the Republic of Ghana, was used in this study. Communities within the area are into commercial and subsistence farming, mainly maize, cocoa, and vegetable farming (Figure 1). There are also pockets of fish farming and illegal mining activities in the study area. The area is relatively flat with moist semideciduous land cover $[1,27]$. The vegetation, which has been left to protect the basin, has been destroyed by anthropogenic activities [12]. There are dry and rainy seasons in the study area. The mean annual rainfall is $1,220 \mathrm{~mm}$. The average yearly temperature is $25.8^{\circ} \mathrm{C}$ [25]. Average humidity is high and ranges between 75 and $85 \%$. The yearly evapotranspiration is $1500 \mathrm{~mm}$. The average runoff is $2774 \mathrm{~mm}^{3}$ [27].

2.2. Study Design and Sampling Site Selection. Eighteen (18) fish samples from sampling sites $S_{8}$ and $S_{9}$ in the Asunafo South district of the Tano Basin were studied between November 2016 and October 2017. The levels of seven trace metals mercury $(\mathrm{Hg})$, cadmium $(\mathrm{Cd})$, lead $(\mathrm{Pb})$, copper $(\mathrm{Cu})$, arsenic $(\mathrm{As})$, zinc $(\mathrm{Zn})$, and chromium (Cr) in the muscles of fish samples from River Tano were studied. The selection of these metals was based on their toxicity, medical importance, bioaccumulation, and persistence [28]. The study area was mapped and georeferenced with the aid of a hand-held Garmin 62SC Geographical Positioning System appliance [12].

2.3. Sampling and Sample Treatment. Eighteen (18) fish samples, which were made up of ten (10) species, were studied. The species were Mormyrus rume, Leptocypris niloticus, Oreochromis niloticus, Chrysichthys johnelsi, Clarias gariepinus, and Parachanna obscura, Sarotherodon melanotheron, Ctenopoma gariepinus, Sarotherodon galilaeus and Ctenopoma kingsleyae. Out of the 18 fish samples, 10 were males, while eight were females. Fish traps were set up at sites $\mathrm{S}_{8}$ and $\mathrm{S}_{9}$ and left to stay overnight. The fish caught in the net were collected and sorted according to species into brand-new polyethylene zip bags. They were zipped, labeled, and stored in an ice chest on ice. The length and sex of the fish samples were determined with the aid of officers from the fisheries Department of the Bono Region. The samples collected were transported to Ghana Atomic Energy Commission, where the analyses of heavy metals were done.

2.4. Analysis of Samples. The acid digestion method which was previously described by Benson et al. [29], Huang et al. [26], and Morshy et al. [9] was used. Each fish sample was washed three times with deionized water to avert any possible contamination [30, 31]. Each washed sample was dissected using stainless steel scalpels to remove the muscle. The muscle (which is the most edible part) grounded and homogenised using the domestic food blender as previously described by Rajeshkumar and $\mathrm{Li}$ [3]. One gram $(1.0 \mathrm{~g})$ of the powdered sample was digested using an automatic microwave system, a mixture of $\mathrm{HNO}_{3}: \mathrm{H}_{2} \mathrm{O}_{2}$, deionized water in the ratio of $5: 2: 1$ as described previously by Huang et al. [26]. The mixture was left at room temperature to cool, after which it was diluted with $20 \mathrm{~mL}$ of distilled water and filtered. The filtrate was kept and analysed for heavy metals ( $\mathrm{Cd}, \mathrm{Cu}, \mathrm{Pb}, \mathrm{Zn}, \mathrm{As}, \mathrm{Hg}$, and $\mathrm{Cr}$ ) using PerkinElmer (PinAACle 900T) Atomic Absorption Spectrophotometer (AAS). The analysis of $\mathrm{Hg}$ followed the hydride generation method of AAS where cold vapour was used. For quality control, the $\mathrm{HNO}_{3}$ and $\mathrm{H}_{2} \mathrm{O}_{2}$ used in this analysis were all guaranteed reagents. Duplicate samples were analysed and for each sample, trace metal concentration in $\mathrm{mg} / \mathrm{kg}$ per fish sample was then calculated using

$$
\text { concentration of the metal in } \mathrm{mg} / \mathrm{kg} \text { of fish }=\frac{\text { AAS reading } \times \text { volume of the extract }}{\text { mass of fish digested }} \text {. }
$$

2.5. Data Analysis. The data obtained were entered in EXCEL spreadsheet and imported into $R$ software for analysis. The mean and standard deviation for each heavy metal was calculated [12]. Multivariate statistical approach including principal component analysis (PCA) was performed to determine the spread of metals in fish using JMP statistical 


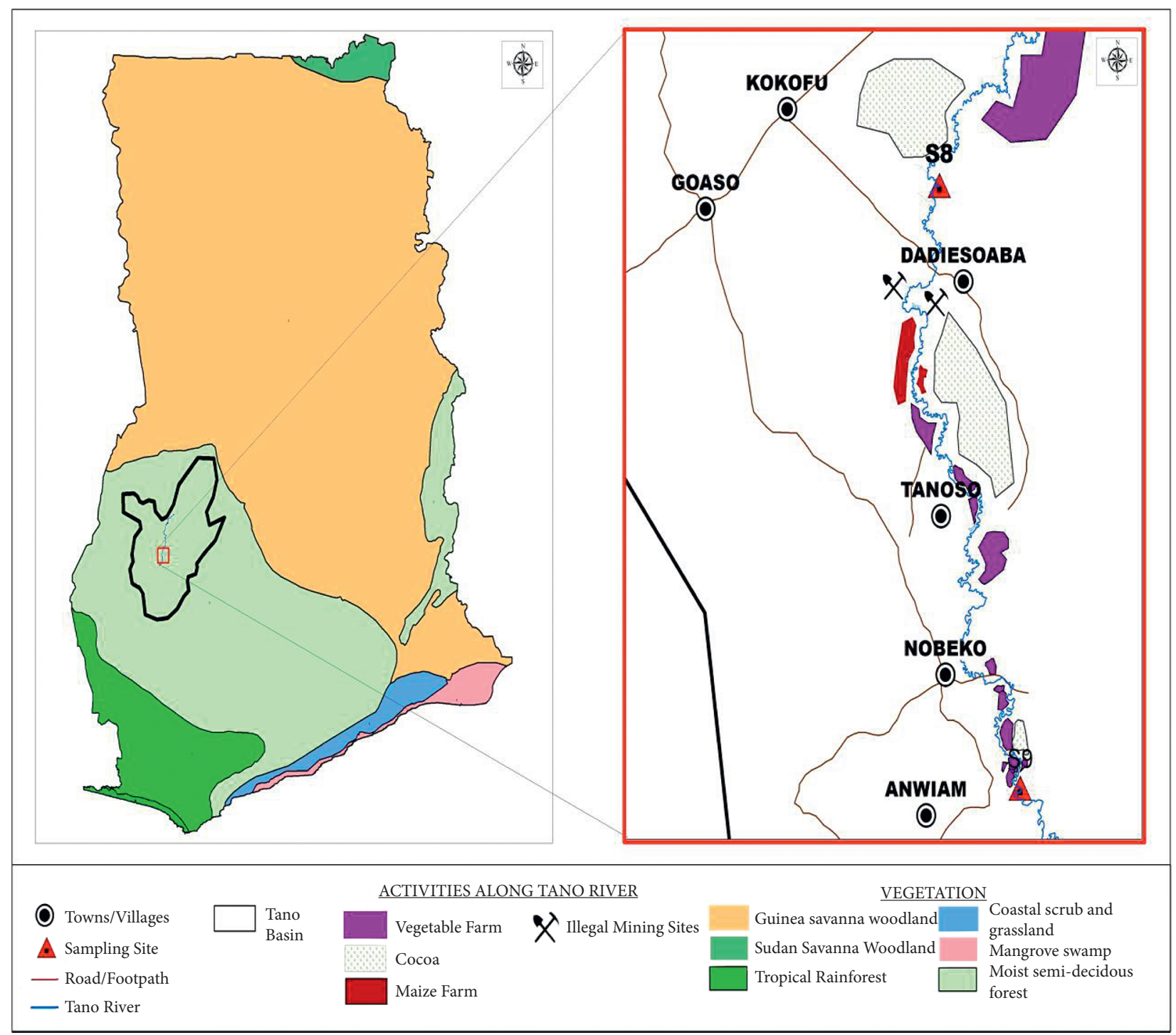

Figure 1: Map of Ghana showing the Tano River catchment in the Asunafo South District, sampling sites, and the land use.

software v. 10 (SAS Institute). The principal components were extracted with eigenvalues more than one through varimax rotation. The purpose of this analysis was to identify the possible source of heavy metals [32]. In this data analysis, $p$ value $<0.05$ was assumed to be statistically significant.

Fulton condition factor $(Q)$ was used to assess the length-weight relationship of the fish samples and the fish conditions in the river according to (2), which was previously described and used by Ahmed et al. [33], Sekitar [34], and Jin et al. [35]:

$$
Q=100 \times \frac{w}{L^{3}},
$$

where $W$ is the total body weight of fish in grams $(g), L$ is the total length of fish in centimeters $(\mathrm{cm})$, and $Q$ is the Fulton's condition factor: $Q \leq 1$ means the condition is poor, $Q=1.2$ means the condition is moderate, and $Q \geq 1.4$ means the condition is proportionally good $[34,36]$.
Human health risk assessment was computed using USEPA [37] methodology with some modifications as previously described by Huang et al. [26]. The estimated daily intake (EDI) for each heavy metal in muscle of a given fish sample was calculated using the product per capita fish consumption in Ghana ( $25 \mathrm{~kg} /$ person/year), as given by MoFA [38]. The measured metal concentration $(\mathrm{mg} / \mathrm{kg}$ ) was divided by the average body weight according to

$$
\mathrm{EDI}=\frac{\mathrm{FIR} \times \mathrm{C}}{\mathrm{BW}},
$$

where $F_{\mathrm{IR}}$ is the ingestion rate of fish and fish products, which is $25 \mathrm{~kg} /$ person/year per adult [38], $C$ is the measured metal concentration in fish in $\mathrm{mg} / \mathrm{kg}$, and $\mathrm{BW}$ is the average body weight $=70 \mathrm{~kg}$ for adults.

Target hazard quotient (THQ) was used to compute the potential noncarcinogenic risk assessment of metals in fish samples in this study. The THQ was expressed as the ratio of 
the EDI to an oral reference dose $R f D$ in $\mu \mathrm{g} / \mathrm{kg} /$ day value as indicated by (4) and previously used by USEPA [37]. The reference doses (RfD) for the metals $\mathrm{Cr}, \mathrm{Zn}, \mathrm{As}, \mathrm{Cd}, \mathrm{Pb}$, and $\mathrm{Hg}$ in $\mu \mathrm{g} / \mathrm{kg} /$ day are $3,300,0.3,1.0,1.5$, and 0.3 , respectively $[26,39]$.

$$
\mathrm{THQ}=\frac{\mathrm{EDI}}{R f D} .
$$

A THQ $>1$ implies that the exposed populace will experience adverse health risks $[18,26]$. Alternatively, a THQ $<1$ means noncarcinogenic risk for the exposed consumers. The carcinogenic risk index (CRI) was computed for As, Cd, and $\mathrm{Cr}$ in the fish samples using (5) as previously used by Huang et al. [26]. The oral intake of carcinogenic slope factor (SF) for As, Cr, and Cd is $0.38,0.50$, and 1.50 , respectively $[26,33]$.

$$
\mathrm{CRI}=\frac{\mathrm{FIR}}{\mathrm{BW}} \times \mathrm{SF} \times C,
$$

where CRI is a carcinogenic risk indicator, and CRI $<1.0 \times 10-6$ which means that the fish is safe for human consumption. Alternatively, CRI $>1.0 \times 10-4$ means excessive carcinogenic risks [26, 37].

\section{Quality Control and Quality Assurance}

Strict QC and QA protocols were observed in terms of precision, accuracy, and representativeness. All instruments used in this study were calibrated and validated using the specificity method as previously described by El-Gawad [40]. The glassware used in this study were soaked in $10 \%$ of $\mathrm{HNO}_{3}$ overnight and washed with deionized water several times and dried before using them. Acid digestion of the samples was validated by preparing, digesting, and analyzing nitric and distilled water in the same way as the fish samples. Deionized organic-free water samples were used as blanks. These were extracted and analysed in the same way as the real samples. During the digestion of fish samples, certified reference materials, SRM 8704 sourced from the National Institute of Standards and Technology, US, were included and prepared in the same way as the fish samples. The recovery ranged between $98 \%$ and $104 \%$.

\section{Results and Discussion}

4.1. Fish Size, Weight, and Sex. The size, weight, and sex of fish samples are indicated in Table 1. The male fish samples were insignificantly longer and wider than the female fish samples. The mean length of male fish samples was $28.8 \pm 14.4 \mathrm{~cm}$, while that of the female was $19.7 \pm 3.35 \mathrm{~cm}$. The mean width of the male fish was $7.32 \pm 2.33 \mathrm{~cm}$, while that of the female was $5.76 \pm 1.17 \mathrm{~cm}$. The male fish samples were significantly heavier than the female fish samples $(p<0.05)$. The average weight of the male fish samples was $120.10 \pm 4.0 \mathrm{~g}$, while that of the female fish samples was $70.33 \pm 0.9 \mathrm{~g}$. The measured weight and size of the fish samples in this study are comparable to what was reported by Bawuro et al. [41] in fish samples from Lake Geriyo in Nigeria. Ahmed et al. [33] reported on fish samples in China, where the female fish samples were bigger and heavier than the male fish samples, contrary to what observed in this study. Variations in fish size, weight, and sex influence metabolic activity and contaminant levels [41].

4.2. Fulton Condition Factors of Fish Samples. Fulton condition factors were used to express the fish conditions in the river. The results are shown in Table 2. The results showed that the Fulton condition factor $(Q)$ was in the range of 1.0-2.53. Mormyrus rume recorded the least $Q$ value. The highest was recorded by Oreochromis niloticus to suggest that the condition of Mormyrus rume was poor, whereas that of Oreochromis niloticus was proportionally good. Fulton condition factor $(Q)$ is used as an index to assess the health conditions of fish in the aquatic environment [35]. Fish with $Q$ values greater than 1.4 are said to be in good condition, whereas those with $Q$ values $\leq 1$ are said to be in poor conditions [34]. Fish with $Q$ values of 1.2 are said to be in moderate conditions [33]. In this study, Mormyrus rume recorded $Q$ value of 1.0 to suggest poor conditions. Sarotherodon galilaeus fish recorded $Q$ value of 1.12 to suggest a moderate condition. The rest recorded $\mathrm{Q}$ values greater than 1.4 to suggest proportionally good conditions. Poor fish conditions similar to what was recorded in Mormyrus rume were also recorded by Ahmed et al. [33] in the Karnaphuli River.

4.3. Heavy Metals in the Muscles of Fish Samples from River Tano. The results for the mean trace metals in the muscles of fish samples are presented in Table 3. The results showed that, apart from $\mathrm{Cu}$, which was below the detection limits, the rest of the heavy metals studied were detected in the muscles of all fish samples. The nondetection of $\mathrm{Cu}$ in the muscles of fish samples may be due to lower concentrations in the river [10]. Cu levels ranging from 0.03 to $0.51 \mu \mathrm{g} / \mathrm{g}$ were reported by Rajeshkumar and Li [3] in fish samples from Taihu Lake in China, contrary to what was observed in this study. Huang et al. [26] also reported $8.33 \mathrm{mg} / \mathrm{kg} \mathrm{Cu}$ in fish samples from Northeast China.

The results of $\mathrm{Pb}$ levels analysed in fish samples were low. They range from $<0.5 \mathrm{mg} / \mathrm{kg}$ fresh weight in S. melanotheron to $0.16 \pm 0.05 \mathrm{mg} / \mathrm{kg}$ in O. niloticus (Table 3). A decreasing order of $\mathrm{Pb}$ accumulation in the muscles of fish species studied is shown in Table 4. From the results, the highest concentration of $\mathrm{Pb}$ in fish muscles was in O. niloticus (Table 4). Similarly, Cd concentrations recorded in the fish samples were also low ranging from $<0.3 \mathrm{mg} / \mathrm{kg}$ in the fresh body weight in O. niloticus, S. galilaeus and C. kingsleyae to $0.03 \pm 0.02 \mathrm{mg} / \mathrm{kg}$ in M. rume (Table 3). An order of Cd levels in the muscles of the fish species studied is shown in Table 4. The results show that a slightly elevated level is established in the muscles of $M$. rume. The levels of As in the fish samples analysed were high (Table 3). They ranged from $1.01 \pm 0.08 \mathrm{mg} / \mathrm{kg}$ in C. gariepinus to $3.00 \pm 0.01 \mathrm{mg} / \mathrm{kg}$ of fresh weight of $M$. rume. The order of As accumulation in the muscles of the fish species studied can be established from Table 4, with the highest As accumulation recorded in M. rume. The results showed elevated levels of $\mathrm{Hg}$ in all fish 
TABLE 1: Comparison between female and male fish dimensions.

\begin{tabular}{lcccccc}
\hline Dependent variables & Sex & $n$ & Weight $(g) \pm$ SD & Mean $(\mathrm{cm}) \pm$ SD & $t$ value & $P$ value \\
\hline \multirow{2}{*}{ Length } & Male & 10 & N/A & $28.8 \pm 14.4$ & 1.74 & 0.102 \\
& Female & 8 & N/A & $7.3 \pm 3.35$ & 0.105 \\
Width & Male & 10 & N/A & $5.76 \pm 1.17$ & 1.72 \\
\multirow{2}{*}{ Weight } & Female & 8 & N/A & $14.76 \pm 4.56$ & 1.70 \\
& Male & 10 & $120.10 \pm 4.3$ & $10.32 \pm 1.45$ & $0.012^{\mathrm{a}}$ \\
& Female & 8 & $70.33 \pm 0.9$ & \\
\hline
\end{tabular}

${ }^{a}$ Difference is significant at $p<0.05$.

TABLE 2: Weight-length relationship and condition factor.

\begin{tabular}{|c|c|c|c|c|}
\hline Fish species & Weight $(g) \pm$ SD & Length $(\mathrm{cm}) \pm \mathrm{SD}$ & $Q$ value & Fish condition \\
\hline Mormyrus rume & $531 \pm 0.19$ & $37.5 \pm 0.01$ & 1.0 & Poor \\
\hline Leptocypris niloticus & $308 \pm 0.54$ & $26.5 \pm 0.00$ & 2.19 & Proportionally good \\
\hline Oreochromis niloticus & $252 \pm 0.31$ & $21.5 \pm 0.00$ & 2.53 & Proportionally good \\
\hline Chrysichthys johnelsi & $266 \pm 0.75$ & $22.0 \pm 0.02$ & 2.50 & Proportionally good \\
\hline Clarias gariepinus & $108 \pm 0.38$ & $17.0 \pm 0.01$ & 2.20 & Proportionally good \\
\hline Parachanna obscura & $99.5 \pm 0.21$ & $19.0 \pm 0.05$ & 1.45 & Proportionally good \\
\hline Saro. melanotheron & $58.2 \pm 1.01$ & $16.0 \pm 0.02$ & 1.42 & Proportionally good \\
\hline Ctenopoma gariepinus & $91.0 \pm 0.54$ & $17.0 \pm 0.00$ & 1.85 & Proportionally good \\
\hline Sarotherodon galilaeus & $73.5 \pm 0.59$ & $18.7 \pm 0.01$ & 1.12 & Moderate \\
\hline Ctenopoma kingsleyae & $120 \pm 0.20$ & $20.4 \pm 0.06$ & 1.41 & Proportionally good \\
\hline
\end{tabular}

The $Q$ value means the Fulton condition factor.

TABLE 3: Levels of heavy metals in the muscles of fish samples from River Tano.

\begin{tabular}{|c|c|c|c|c|c|c|c|}
\hline \multirow{2}{*}{ Fish species } & \multicolumn{7}{|c|}{ Heavy metal concentration \pm SD $(\mathrm{mg} / \mathrm{kg})$} \\
\hline & $\mathrm{Cu}$ & $\mathrm{Pb}$ & $\mathrm{Cd}$ & As & $\mathrm{Hg}$ & $\mathrm{Cr}$ & $\mathrm{Zn}$ \\
\hline M. rume & $<0.3$ & $0.12 \pm 0.06$ & $0.03 \pm 0.02$ & $3.00 \pm 0.01$ & $1.01 \pm 0.03$ & $14.9 \pm 0.02$ & $9.91 \pm 1.30$ \\
\hline L. niloticus & $<0.3$ & $0.10 \pm 0.01$ & $0.01 \pm 0.05$ & $1.55 \pm 0.10$ & $1.1 \pm 0.14$ & $32.2 \pm 14.3$ & $11.7 \pm 4.67$ \\
\hline O. niloticus & $<0.3$ & $0.16 \pm 0.05$ & $<0.3$ & $1.52 \pm 0.70$ & $0.58 \pm 0.69$ & $27.0 \pm 36.6$ & $10.8 \pm 2.10$ \\
\hline C. johnelsi & $<0.3$ & $0.08 \pm 0.04$ & $0.02 \pm 0.10$ & $2.17 \pm 0.20$ & $1.57 \pm 2.0$ & $33.0 \pm 15.5$ & $12.2 \pm 8.01$ \\
\hline C. gariepinus & $<0.3$ & $0.13 \pm 0.03$ & $0.01 \pm 0.07$ & $1.01 \pm 0.08$ & $1.00 \pm 0.04$ & $16.1 \pm 2.40$ & $10.8 \pm 2.76$ \\
\hline P. obscura & $<0.3$ & $0.04 \pm 0.01$ & $0.01 \pm 0.01$ & $1.57 \pm 0.65$ & $1.58 \pm 0.74$ & $17.9 \pm 11.3$ & $12.4 \pm 3.38$ \\
\hline S. melanotheron & $<0.3$ & $<0.5$ & $0.01 \pm 0.01$ & $1.09 \pm 0.17$ & $2.07 \pm 1.90$ & $17.8 \pm 0.07$ & $8.42 \pm 6.15$ \\
\hline C. gariepinus & $<0.3$ & $0.01 \pm 0.10$ & $0.01 \pm 0.06$ & $2.61 \pm 0.55$ & $2.01 \pm 1.40$ & $40.4 \pm 10.4$ & $12.5 \pm 2.17$ \\
\hline S. galilaeus & $<0.3$ & $0.02 \pm 0.01$ & $<0.3$ & $2.57 \pm 0.82$ & $2.02 \pm 1.39$ & $57.9 \pm 4.2$ & $12.5 \pm 3.5$ \\
\hline C. kingsleyae & $<0.3$ & $0.02 \pm 0.04$ & $<0.3$ & $2.54 \pm 0.69$ & $2.52 \pm 0.70$ & $52.4 \pm 20.4$ & $10.1 \pm 12.7$ \\
\hline
\end{tabular}

samples (Table 3 ). The results showed that the levels of $\mathrm{Hg}$ in the fish samples ranged from $0.58 \pm 0.69 \mathrm{mg} / \mathrm{kg}$ of fresh body weight of $O$. niloticus to $2.52 \pm 0.70 \mathrm{mg} / \mathrm{kg}$ in C. kingsleyae. The order of $\mathrm{Hg}$ accumulation in the muscles of the fish species studied recorded the highest $\mathrm{Hg}$ concentration in C. kingsleyae (Table 4). The levels of Cr concentrations in the fish samples studied are high (Table 3 ). They ranged from $16.10 \pm 0.2 \mathrm{mg} / \mathrm{kg}$ in M. rume.to $57.9 \pm 4.2 \mathrm{mg} / \mathrm{kg}$ in Sarotherodon galilaeus. The order of $\mathrm{Cr}$ accumulation studied in the muscles of the fish species showed the highest accumulation in S. galilaeus (Table 4). Zn levels in the fish samples were low (Table 3). They ranged from $8.42 \pm 6.15 \mathrm{mg} / \mathrm{kg}$ fresh weight in $S$. melanotheron to $12.5 \pm 3.5 \mathrm{mg} / \mathrm{kg}$ in S. galilaeus (Table 3). A decreasing order of $\mathrm{Zn}$ accumulation in the muscles of fish species studied is shown in Table 4. From the results, the highest concentration of $\mathrm{Zn}$ in fish muscles was in S. galilaues (Table 4).
The general order of increasing metal accumulation in the muscles of fish species is $\mathrm{Cu}<\mathrm{Cd}<\mathrm{Pb}<\mathrm{Hg}<\mathrm{As}<\mathrm{Zn}<\mathrm{Cr}$. The least metal found in the muscles of the fish species studied was $\mathrm{Cu}$ and the highest was $\mathrm{Cr}$ (Table 4). The observed trend in the low accumulation of $\mathrm{Cu}$ and $\mathrm{Cd}$ may be due to their low tendency to accumulate in the muscles but high affinity to metabolic organs such as liver and kidney [42]. Pb highly accumulates in the bones compared with the muscles, and this may account for low the accumulation in the fish muscles. Higher accumulation of $\mathrm{Zn}$ in the muscle may be attributed to its being important for the regular physiological and central functions of fish [17]. The observed levels of $\mathrm{Cu}, \mathrm{As}, \mathrm{Pb}, \mathrm{Cr}$, and $\mathrm{Cd}$ in the fish muscles studied were similar to the observations made by Ahmed et al. [33] in fish samples from Karnaphuli River in Bangladesh. Huang et al. [26] also reported on the levels of $\mathrm{Hg}, \mathrm{As}, \mathrm{Pb}, \mathrm{Cu}, \mathrm{Zn}, \mathrm{Cr}$, and $\mathrm{Cd}$ in fish samples from surface water bodies in Northeast China, which were lower 


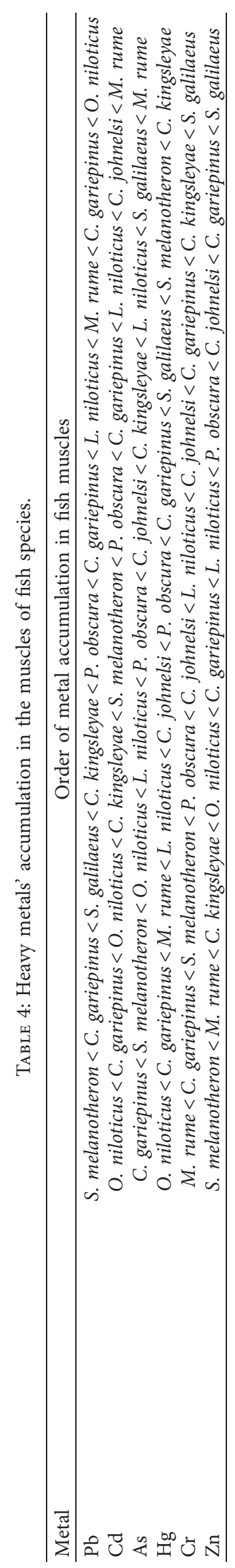


TABLE 5: Noncarcinogenic analysis of metals in fish samples.

\begin{tabular}{lcccccccccccc}
\hline \multirow{2}{*}{ Fish species } & \multicolumn{2}{c}{$\mathrm{Pb}$} & \multicolumn{2}{c}{$\mathrm{Cd}$} & \multicolumn{2}{c}{ As } & \multicolumn{2}{c}{ Hg } & \multicolumn{2}{c}{ Cr } & \multicolumn{2}{c}{ Zn } \\
& EDI & THQ & EDI & THQ & EDI & THQ & EDI & THQ & EDI & THQ & EDI & THQ \\
\hline Mormyrus rume & 0.04 & 0.03 & 0.01 & 0.01 & 1.07 & 3.6 & 0.36 & 1.2 & 5.32 & 1.8 & 3.5 & 0.01 \\
Leptocypris niloticus & 0.38 & 0.25 & 0.01 & 0.01 & 0.55 & 1.8 & 0.39 & 1.3 & 11.5 & 3.8 & 4.18 & 0.01 \\
Oreochromis niloticus & 0.08 & 0.38 & N/A & N/A & 0.05 & 1.8 & 0.21 & 0.69 & 9.64 & 3.2 & 3.85 & 0.01 \\
Chrysichthys johnelsi & 0.03 & 0.19 & 0.01 & 0.01 & 0.77 & 2.6 & 0.56 & 1.9 & 11.8 & 3.9 & 4.36 & 0.01 \\
Clarias gariepinus & 0.05 & 0.30 & 0.01 & 0.01 & 0.36 & 1.2 & 0.38 & 1.2 & 5.75 & 1.9 & 3.85 & 0.01 \\
Parachanna obscura & 0.014 & 0.09 & 0.004 & 0.003 & 0.56 & 1.9 & 0.56 & 1.9 & 6.39 & 2.1 & 4.4 & 0.15 \\
Sarotherodon melanotheron & N/A & N/A & 0.004 & 0.004 & 0.39 & 1.3 & 0.73 & 2.5 & 6.35 & 2.1 & 3.01 & 0.01 \\
Ctenopoma gariepinus & 0.004 & 0.002 & 0.004 & 0.004 & 0.93 & 3.1 & 0.72 & 2.4 & 14.4 & 4.8 & 4.46 & 0.01 \\
Sarotherodon galilaeus & 0.007 & 0.005 & N/A & N/A & 0.917 & 3.0 & 0.721 & 2.4 & 20.8 & 6.9 & 4.46 & 0.01 \\
Ctenopoma kingsleyae & 0.007 & 0.005 & N/A & N/A & 0.906 & 3.0 & 0.899 & 3.0 & 18.7 & 6.2 & 3.605 & 0.01 \\
\hline
\end{tabular}

N/A means not applicable.

than the findings in this study. Awuah [31] reported on As levels in fish samples from the downstream of River Tano and River Ankobra in Ghana, which were comparable to the findings in this study. Asare-Donkor and Adimado [1] reported on $\mathrm{Hg}$ levels in fish similar to this study from the downstream of River Tano. Higher levels of $\mathrm{Cr}$ in fish samples from Douglas Creek in the Qua Iboe Estuary, which were higher than the findings in this study, were reported by Benson et al. [29]. In China, higher Cr concentrations similar to the findings in this study were reported by Rejeshkumar and Li [3] in the Meiliang Bay and Taihu Lake. Heavy metals in the muscles of fish may be attributed to agricultural and municipal runoff $[1,3,10,29]$.

The limits for heavy metal in fish muscles have been set to safeguard public health. The limits differ from country to country and organization to organization. In this study, comparisons were made between the measured heavy metals in the fish muscle studied and the Food and Agriculture Organization limits $[43,44]$ and FAO/WHO [45]. The results showed that $\mathrm{Cd}, \mathrm{Pb}$, and $\mathrm{Zn}$ were lower than the respective limits of FAO/WHO in fish muscles (Table 3). However, thre recorded levels of $\mathrm{As}$ and $\mathrm{Hg}$ exceeded the FAO/WHO limits in fish muscles, which are $0.5 \mathrm{mg} / \mathrm{kg}$ for each of them. The FAO/WHO permissible limits of $\mathrm{Cd}, \mathrm{Pb}$, and $\mathrm{Zn}$ in fish muscles are, respectively, $0.05 \mathrm{mg} / \mathrm{kg}, 0.2 \mathrm{mg} /$ $\mathrm{kg}$, and $30 \mathrm{mg} / \mathrm{kg}$. The United States Food and Drug Administration [46] recommends $12-13 \mathrm{mg} / \mathrm{kg}$ as the limit for $\mathrm{Cr}$ in fish muscles. Comparison with the levels of $\mathrm{Cr}$ in the muscles of fish samples studied revealed that $\mathrm{Cr}$ levels in fish exceeded the limits in fish muscles (Table 3). Ingestion of fish polluted with high levels of $\mathrm{Hg}$, As, and $\mathrm{Cr}$ is associated with health problems, including kidney, liver, and skin cancers $[1,12,26]$. For example, the Minamata disease in Japan in the $60 \mathrm{~s}$ was attributed to methylmercury $(\mathrm{MeHg})$ exposure through seafood consumption [28].

\subsection{Risk Assessment of Heavy Metals in the Muscles of Fish Species}

4.4.1. Noncarcinogenic Risk Analysis of Metals in Fish Samples from River Tano. The results for the noncarcinogenic risk assessments for the adult groups are presented in Table 5. The results showed that the target hazard quotients
(THQs) for $\mathrm{Cd}, \mathrm{Zn}$, and $\mathrm{Pb}$ in fish samples were less than one for adults to suggest no possible noncarcinogenic risks in the consumption of all the fish species studied. However, THQ values for $\mathrm{As}, \mathrm{Cr}$, and $\mathrm{Hg}$ in all the fish species studied for the adult's groups were greater than 1 to suggest possible noncarcinogenic risks to consumers of all the fish species from the river studied. THQ $>1$ for $\mathrm{Hg}$ observed in this study has also been reported by Asare-Donkor and Adimado [1] in fish samples from the downstream of River Tano. In Youngshu Island in China, Wu et al. [47] reported on THQ $>1$ for $\mathrm{Cr}$ in fish samples, comparable to the findings in this study. Contrary to the findings in this study, Huang et al. [26] computed THQ $<1$ for Cr, As, and Hg in fish samples from Northeast China. In the same study, however, THQ $<1$ was recorded for $\mathrm{Pb}$ and $\mathrm{Cd}$, which was similar to the findings in this study. Mohammadi et al. [48] reported on THQ $<1$ for $\mathrm{Cd}, \mathrm{Pb}$, and $\mathrm{Zn}$, which was comparable to the findings in this study for fish samples from Khorramabad in Iran. Benson et al. [29] reported THQ $<1$ for $\mathrm{Zn}, \mathrm{Pb}$, and $\mathrm{Cd}$ in fish samples from Douglas Creek in the Qua Iboe Estuary, which was comparable to the findings in this study. Ashraf et al. [19] also recorded high THQ in some fish samples from Peninsular Malaysia, which is comparable to the computed THQ values in this study. The high THQ values from this study suggest that consumption of fish from River Tano has adverse effects [1,29].

4.5. Carcinogenic Risk Assessment of Metals in Fish Samples. The carcinogenic risk assessment results for $\mathrm{Cd}$, As, and $\mathrm{Cr}$ in fish samples are presented in Table 6. The results showed that the calculated cancer risk index (CRI) for each metal was higher than $1.0 \times 10-4$ in all fish samples for the adult groups of people. A given fish sample is said to be safe for consumption when the CRI value is less than $1.0 \times 10-6$ for a given metal [26]. The observed CRI values in this study suggest potential carcinogenic risks through the consumption of fish samples from River Tano [26, 33, 39].

4.6. Principal Component Analysis (PCA). The results for the PCA are shown in Table 7 and Figure 2. The results indicated that two (2) components with eigen factors greater than 1 , which accounted for $63.81 \%$, were extracted. The 
TABle 6: Carcinogenic risk index for As, Cr, and Cd metals in fish samples.

\begin{tabular}{|c|c|c|c|c|c|c|}
\hline \multirow{2}{*}{ Fish species } & \multicolumn{2}{|c|}{$\mathrm{Cd}$} & \multicolumn{2}{|c|}{ As } & \multicolumn{2}{|c|}{$\mathrm{Cr}$} \\
\hline & EDI & CRI & EDI & CRI & EDI & CRI \\
\hline Mormyrus rume & 0.01 & $1.5 .510^{-2}$ & 1.07 & $4.0 \times 10^{-1}$ & 5.32 & 2.66 \\
\hline Leptocypris niloticus & 0.01 & $1.5 .510^{-2}$ & 0.55 & $2.1 \times 10^{-1}$ & 11.5 & 5.75 \\
\hline Oreochromis niloticus & $\mathrm{N} / \mathrm{A}$ & $\mathrm{N} / \mathrm{A}$ & 0.05 & $1.9 \times 10^{-2}$ & 9.64 & 4.82 \\
\hline Chrysichthys johnelsi & 0.01 & $1.5 .510^{-2}$ & 0.77 & $2.9 .910^{-1}$ & 11.8 & 5.9 \\
\hline Clarias gariepinus & 0.01 & $1.5 .510^{-2}$ & 0.36 & $1.4 .410^{-1}$ & 5.75 & 2.9 \\
\hline Parachanna obscura & 0.004 & $6.0 .010^{-3}$ & 0.56 & $2.1 .110^{-1}$ & 6.39 & 3.2 \\
\hline Sarotherodon melanotheron & 0.004 & $6.0 .010^{-3}$ & 0.39 & $1.5 .510^{-1}$ & 6.35 & 3.2 \\
\hline Ctenopoma gariepinus & 0.004 & $6.0 .010^{-3}$ & 0.93 & $3.5 .510^{-1}$ & 14.4 & 7.1 \\
\hline Sarotherodon galilaeus & $\mathrm{N} / \mathrm{A}$ & N/A & 0.917 & $3.5 .510^{-1}$ & 20.8 & 10.4 \\
\hline Ctenopoma kingsleyae & $\mathrm{N} / \mathrm{A}$ & N/A & 0.906 & $3.4 .410^{-1}$ & 18.7 & 9.35 \\
\hline
\end{tabular}

N/A means not applicable.

TABLE 7: Varimax component matrix for heavy metals in fish.

\begin{tabular}{lccccccc}
\hline & F1 & F2 & F3 & F4 & F5 & F6 & F7 \\
\hline Eigenvalue & 3.2723 & 1.1945 & 0.9492 & 0.6333 & 0.5162 & 0.2501 & 0.1843 \\
Variability (\%) & 46.7472 & 17.0645 & 13.5605 & 9.0471 & 7.3743 & 3.5734 & 2.6329 \\
Cumulative (\%) & 46.7472 & 63.8117 & 77.3723 & 86.4194 & 93.7937 & 97.3671 & 100.000 \\
\hline
\end{tabular}

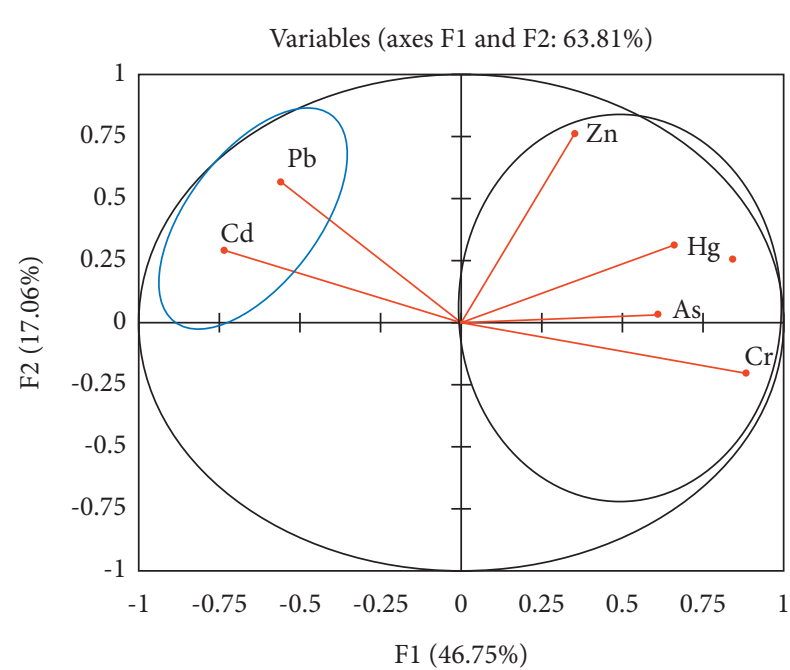

Figure 2: Principal composite analysis for heavy metals in fish samples.

first component (F1) accounted for $46.7 \%$ of the loading and was dominated by $\mathrm{Hg}, \mathrm{As}, \mathrm{Zn}$, and $\mathrm{Cr}$. The second component (F2), which accounted for $17.06 \%$, was dominated by high loadings of $\mathrm{Pb}$ and $\mathrm{Cd}$. The observed connotation between $\mathrm{Cd}$ and $\mathrm{Pb}$ in this study is similar to what was observed by Wang et al. [49] in the Huaihe River in China and was attributed to applying agrochemicals and industrial discharge. Similarly, the association between $\mathrm{Hg}$, As, $\mathrm{Zn}$, and $\mathrm{Cr}$ may suggest that they are also coming from a common source, possibly an agricultural runoff, pesticide application, or geological sources [10]. In the Weija Reservoir in Ghana, Ansah et al. [50] reported on a strong association between As and $\mathrm{Hg}$ similar to what was observed in this study.

\section{Conclusion}

The levels of trace metals in fish samples from River Tano and the risks associated with their consumption have revealed that the levels of $\mathrm{Cu}$ in the muscles of all fish samples studied were below detection limits. However, some levels of $\mathrm{As}, \mathrm{Cd}, \mathrm{Hg}, \mathrm{Pb}, \mathrm{Zn}$, and $\mathrm{Cr}$ were detected in muscles of all fish samples. Mormyrus rume fish species was under stress in the river, whereas the remaining fish species were proportionally in good condition. The measured levels of $\mathrm{Cd}, \mathrm{Zn}, \mathrm{Cu}$, and $\mathrm{Pb}$ were within the Food and Agriculture Organization limits of metals in fish muscles. However, the levels of $\mathrm{Hg}, \mathrm{As}$, and $\mathrm{Cr}$ in all fish samples exceeded the respective recommended permissible levels in fish. The target hazard quotients for $\mathrm{Cd}, \mathrm{Zn}$, and $\mathrm{Pb}$ in fish samples were less than 1, suggesting no possible noncarcinogenic risk of metals for adults. On the other hand, $\mathrm{As}, \mathrm{Cr}$, and $\mathrm{Hg}$ recorded target hazard quotient values greater than 1 for adults in all fish sample, suggesting possible noncarcinogenic risks to consumers of fish from the river. Additionally, high carcinogenic risks were recorded for As, Cr, and $\mathrm{Hg}$ for all fish samples in adults, making the consumption of fish from River Tano unsafe. Strong association was found between $\mathrm{Hg}, \mathrm{As}, \mathrm{Zn}$, and $\mathrm{Cr}$ and between $\mathrm{Pb}$ and $\mathrm{Cd}$ suggesting a common source, possibly industrial effluent discharge and agricultural runoff. Continuous monitoring of trace metals in fish from River Tano and the enforcement of the buffer zone policy in the Tano Basin are highly recommended.

\section{Data Availability}

All data used in this manuscript are available at the discretion of the authors. 


\section{Ethical Approval}

This manuscript has never been published in any journal or sent to any journal for consideration and publication. Strict scientific ethical standards were adhered to.

\section{Consent}

The authors are fully responsible for this manuscript and have therefore given their respective consent to the publication of this manuscript.

\section{Disclosure}

None of the authors has played any role of funding sponsors in the choice of the research project; design of the study; in the collection, analyses, or interpretation of data; in the writing of the manuscript; or in the decision to publish the results.

\section{Conflicts of Interest}

The authors declare no conflicts of interest.

\section{Authors' Contributions}

Nyantakyi A. J. conceptualized the research topic, formulated the objectives and methodology of the research, and participated in the data collection and analysis. Samuel W. carried out both the laboratory and field investigation and the data curation of the research work. Fei-Baffoe B. carried out laboratory work and assisted in the writing of the manuscript. Akoto O. reviewed and edited the manuscript.

\section{Acknowledgments}

The authors acknowledge the immense contribution by the Environmental Protection Agency of Ghana and Water Resources Commission of Ghana for the permit and making all necessary resources available to carry out this essential research.

\section{References}

[1] N. K. Asare-Donkor and A. A. Adimado, "Influence of mining-related activities on levels of mercury in water, sediment, and fish from the Ankobra and Tano River basins in South Western Ghana," Environmental Systems Research, vol. 5, no. 1, 2016.

[2] F. K. E. Nunoo, B. Asiedu, K. Amador et al., "Marine fisheries catches in Ghana: historic reconstruction for 1950 to 2010 and current economic impacts," Reviews in Fisheries Science and Aquaculture, vol. 22, no. 4, pp. 274-283, 2014.

[3] S. Rajeshkumar and X. Li, "Bioaccumulation of heavy metals in fish species from the Meiliang Bay, Taihu Lake, China," Toxicology Reports, vol. 5, pp. 288-295, 2018.

[4] A. Banunle, B. Fei-Baffoe, and K. G. Otchere, "Determination of the physico-chemical properties and heavy metal status of the Tano river along the catchment of the Ahafo mine in the BrongAhafo region of Ghana," Journal of Environmental and Analytical Toxicology, vol. 8, no. 3, 2018.
[5] K. Sekabira, H. O. Origa, T. A. Basamba, G. Mutumba, and E. Kakudidi, "Assessment of heavy metal pollution in the urban stream sediments and its tributaries," International Journal of Environmental Science and Technology, vol. 7, no. 3, pp. 435-446, 2010.

[6] A. Maurya, T. Negi, and K. N. Negi, "Seasonal assessment of heavy metal pollution in water and sediment of fish pond at Bhagwanpur, Rookee (UK), India," The Asian Journal of Animal Science, vol. 12, pp. 16-22, 2018.

[7] M. M. N. Authma, M. S. Zaki, E. A. Khalla, and H. H. Abbas, "Use of fish as bioindicator of the effects of heavy metal pollution," Journal of Aquaculture Research and Development, vol. 6, no. 4, pp. 32-13, 2015.

[8] N. Malik, A. K. Biswas, T. A. Qureshi, K. Borana, and R. Virha, "Bioaccumulation of heavy metals in fish tissues of a freshwater lake of Bhopal," Environmental Monitoring and Assessment, vol. 160, no. 1-4, pp. 267-276, 2010.

[9] A. E. M. A. Morshdy, W. S. Darwish, J. R. M. Daoud, and M. A. M. Sebak, "Estimation of metal residues in Oreochromis niloticus and Mugil cephalus intended for human consumption in Egypt: a health risk assessment study with some reduction trials," Journal of Consumer Protection and Food Safety, vol. 14, no. 1, pp. 81-91, 2019.

[10] A. J. Nyantakyi, O. Akoto, and B. Fei-Baffoe, "Seasonal variations in heavy metals in water and sediment samples from River Tano in the Bono, Bono east, and Ahafo regions, Ghana," Environmental Monitoring and Assessment, vol. 191, no. 9, p. 570, 2019.

[11] A. Pretto, V. L. Loro, V. M. Morsch et al., "Alterations in carbohydrate and protein metabolism in silver catfish (Rhamdia quelen) exposed to cadmium," Ecotoxicology and Environmental Safety, vol. 100, pp. 188-192, 2014.

[12] A. J. Nyantakyi, Pollution profile and hydrochemical evaluation of River Tano, Ghana, PhD Dissertation, Kwame Nkrumah University of Science and Technology, Kumasi, Ghana, 2020.

[13] M. Saleem, J. Iqbal, and M. H. Shah, "Geochemical speciation, anthropogenic contamination, risk assessment and source identification of selected metals in freshwater sediments-a case study from Mangla Lake, Pakistan," Environmental Nanotechnology, Monitoring and Management, vol. 4, pp. 27-36, 2015.

[14] R. N. Kumar, R. Solanki, and J. I. N. Kumar, "Seasonal variation in heavy metal contamination in water and sediments of river Sabarmati and Kharicut canal at Ahmedabad, Gujarat," Environmental Monitoring and Assessment, vol. 185, no. 1, pp. 359-368, 2013.

[15] Y. S. Saleh and M.-A. S. Marie, "Assessment of metal contamination in water, sediment, and tissues of Arius thalassinus fish from the red sea coast of Yemen and the potential human risk assessment," Environmental Science and Pollution Research, vol. 22, no. 7, pp. 5481-5490, 2014.

[16] H. Yao, X. Qian, H. Gao, Y. Wang, and B. Xia, "Seasonal and spatial variations of heavy metals in two typical Chinese rivers: concentrations, environmental risks, and possible sources," International Journal of Environmental Research and Public Health, vol. 11, no. 11, pp. 11860-11878, 2014.

[17] C. Korkmaz, Ö. Ay, C. Çolakfakioğlu, B. Cicik, and C. Erdem, "Heavy metal levels in muscle tissues of Solea solea, Mullus barbatus and Sardina pilchardus marketed for consumption in Mersin, Turkey," Water, Air, and Soil Pollution, vol. 228, 2017.

[18] M. Yipel and E. Yarsan, “A risk assessment of heavy metal concentrations in fish and an invertebrate from the gulf of 
antalya," Bulletin of Environmental Contamination and Toxicology, vol. 93, no. 5, pp. 542-548, 2014.

[19] M. A. Ashraf, M. J. Maah, and I. Yusoff, "Assessment of heavy metals in fish samples of mined-out ponds, Bestari Jaya, Peninsular Malaysia," Proceedings of the National Academy of Sciences, vol. 77, pp. 57-67, 2011.

[20] S. Tekin-Özan and A. Nurşah, "Relationship of heavy metals in water, sediment and tissues with total length, weight and seasons of Cyprinus carpio L., 1758 from işikli lake (Turkey)," Pakistan Journal of Zoology, vol. 44, no. 5, pp. 1405-1416, 2012.

[21] S. H. Zhang and Y. J. Yi, “The relationships between fish heavy metal concentrations and fish size in the upper and middle reaches of Yangtze River," Procedia Environmental Sciences, vol. 13, pp. 1699-1707, 2012.

[22] S. Cobbina, A. Duwiejuah, R. Quansah, S. Obiri, and N. Bakobie, "Comparative assessment of heavy metals in drinking water sources in two small-scale mining communities in northern Ghana," International Journal of Environmental Research and Public Health, vol. 12, no. 9, pp. 10620-10634, 2015.

[23] J. K. Ideriah, F. N. Ikpee, and M. Nwanjoku, "Distribution and speciation of heavy metals in crude oil-contaminated soils from Niger Delta, Nigeria," World Environment, vol. 3, no. 1, pp. 18-28, 2013.

[24] W. H. Tan, R. Tair, S. O. M. Ali, A. Taibe, F. Sualin, and C. Payus, "Distribution of heavy metals in seawater and surface sediment in coastal area of Tuaran, Sabah," Transactions on Science and Technology, vol. 3, no. 1-2, pp. 114-122, 2016.

[25] J. Adiyiah Nyantakyi, B. Fei-Baffoe, and O. Akoto, "Seasonal variations in physicochemical and nutrient water quality of River Tano in Ghana," International Journal of Environmental Chemistry, vol. 4, no. 1, pp. 1-12, 2020.

[26] X. Huang, D. Qin, L. Gao et al., "Distribution, contents and health risk assessment of heavy metal(loid)s in fish from different water bodies in Northeast China," RSC Advances, vol. 9, no. 57, pp. 33130-33139, 2019.

[27] WRC, "Water resources commission:Tano river basin - integrated water resources management plan (IWRMP)," pp. 1-43, 2012.

[28] J. Shi, X. Ji, Q. Wu et al., "Tracking mercury in individual tetrahymena using a capillary single-cell inductively coupled plasma mass spectrometry online system," Analytical Chemistry, vol. 92, no. 1, pp. 622-627, 2020.

[29] N. U. Benson, W. U. Anake, J. P. Essien, P. Enyong, and A. A. Olajire, "Distribution and risk assessment of trace metals in Leptodius exarata, surface water and sediments from Douglas creek in the Qua Iboe Estuary," Journal of Taibah University for Science, vol. 11, no. 3, pp. 434-449, 2017.

[30] A. K. Anim, E. K. Ahialey, G. O. Duodu, M. Ackah, and N. O. Bentil, "Accumulation profile of heavy metals in fish samples from Nsawam, along the Densu river, Ghana," Research Journal of Environmental and Earth Sciences, vol. 3, no. 1, pp. 56-60, 2011.

[31] G. K. Awuah, Assessment of heavy metal concentrations in sediments, water, and fish from the Ankobra and Tano River Basins in Ghana, MSc thesis, 1-58, University of Ghana, Accra, Ghana, 2016.

[32] Z. Zhang, J. Abuduwailli, and F. Jiang, "Heavy metal contamination source and pollution assessment of surface water in the Tianshan Mountains in China," Environmental Monitoring and Assessment, vol. 187, no. 2, pp. 1-13, 2015.

[33] A. Ahmed, S. Sultana, A. Habib, H. Ullah, N. Musa, and M. B. Hossain, "Bioaccumulation of heavy metals in some commercial important fishes from a tropical river estuary," PLoS One, vol. 14, no. 10, 2019.

[34] P. K. A. Sekitar, M. Hamid, M. Mansor, and N. Sam, "Lengthweight relationship and condition factor of fish population in Temengor reservoir, Indication of environmental health," Sains Malaysiana, vol. 44, pp. 61-66, 2015.

[35] S. Jin, X. Yan, H. Zhang, and W. Fan, "Weight-length relationships and Fulton's condition factors of skipjack tuna (Katsuwonus pelamis) in the western and central Pacific Ocean," PeerJ, vol. 3, Article ID e758, 2015.

[36] S. N. Datta, V. I. Kaur, A. Dhawan, and G. Jassal, "Estimation of length-weight relationship and condition factor of spotted snakehead Channa punctata (Bloch) under different feeding regimes," SpringerPlus, vol. 2, no. 1, p. 436, 2013.

[37] USEPA, Guidance for Assessing Chemical Contaminant Data for Use in Fish Advisories, and Risk Assessment and Fish Consumption Limits, USEPA, Washington DC, USA, 2000.

[38] MoF, Ministry of Food and Agriculture - Bono Regional 2018 Annual Report, Ministry of Food and Agriculture, Accra, Ghana, 2018.

[39] USEPA, United States Environmental Protection Agency, Regional Screening Level (RSL) Resident Fish Table, USEPA, Washington DC, USA, 2018.

[40] H. A. El-Gawad, "Validation method of organochlorine pesticides residues in water using gas chromatography quadruple mass," Journal of Water Science, vol. 30, no. 2, pp. 96-107, 2016.

[41] A. A. Bawuro, R. B. Voegborlo, and A. A. Adimado, "Bioaccumulation of heavy metals in some tissues of fish in lake Geriyo, adamawa state, Nigeria," Journal of Environmental and Public Health, vol. 2018, pp. 1-7, 2018.

[42] M. Mohammed, F. Soufiane, E. M. Mohammed, and S. Youssef, "Mercury, lead, and cadmium in the muscles of five fish species from the mechraa-hammadi dam in Morocco and health risks for their consumers," Journal of Toxicology, 2021.

[43] FAO, Compilation of Legal Limits for Hazardous Substances in Fish and Fishery Products, pp. 5-100, Food and Agriculture Organization, Quebec City, Canada, 1983.

[44] FAO, Heavy Metal Regulations-Faolex, FAO, Quebec City, Canada, 2003.

[45] FAO/WHO, "Codex alimentarius-general standards for contaminants and toxins in food," Schedule 1 Maximum and Guideline Levels for Contaminants and Toxins in Food, FAO/ WHO, Codex Committee, Rotterdam, Netherlands, 2002.

[46] USFDA, Food and Drug Administration Guidance Document for Chromium in Shellfish, DHHS/FDA/CFSAN/Office of Seafood, Washington DC, USA, 1993.

[47] Z. Wu, Y. Xu, M. Cai et al., "Metals in fishes from Yongshu Island, Southern South China Sea: human health risk assessment," Journal of Toxicology, vol. 2017, Article ID 2458293, 2017.

[48] A. A. Mohammadi, A. Zarei, S. Majidi et al., "Carcinogenic and non-carcinogenic health risk assessment of heavy metals in drinking water of Khorramabad, Iran," Methods (Orlando), vol. 6, pp. 1642-1651, 2019. 
[49] H. Wang, L. Sun, Z. Liu, and Q. Luo, "Spatial distribution and seasonal variations of heavy metal contamination in surface waters of Liaohe River, Northeast China," Chinese Geographical Science, vol. 27, no. 1, pp. 52-62, 2017.

[50] E. Ansah, D. Nukpezah, and J. N. Horgah, "Levels, and the distribution of heavy metals in Weija reservoir, accra, Ghana," West African Journal of Applied Ecology, vol. 26, no. 1, pp. 74-88, 2018. 